\title{
The effects of oestradiol benzoate, progesterone, relaxin and ovariectomy on cervical extensibility in the late pregnant rat
}

\author{
M. Hollingsworth, Catherine N. M. Isherwood and R. W. Foster \\ Departments of Pharmacology, Materia Medica and Therapeutics and Child Health, Medical \\ School, University of Manchester, Oxford Road, Manchester, M13 9PT, U.K.
}

\begin{abstract}
Summary. Cervical extensibility increased from Day 16 to term in the pregnant rat. Following ovariectomy on Day 16 of pregnancy the cervix became as inextensible by Day 20 as that of non-pregnant animals. Fetal growth was maintained in rats ovariectomized on Day 16 if given oestradiol benzoate plus progesterone but cervical extensibility only increased to a small extent. Relaxin given to these animals further increased cervical extensibility, suggesting a role for this hormone.
\end{abstract}

\section{Introduction}

Normal parturition depends upon co-ordinated uterine activity and cervical dilatation. The properties of the rat cervix show two distinct changes during pregnancy. There are increases in both the inner circumference of the cervix (associated with increased tissue mass) and its extensibility or ability to extend continuously under prolonged loading (Harkness \& Harkness, 1959; Harkness \& Nightingale, 1962; Rundgren, 1974). In the rat both properties increase progressively from about Day 12 until the end of pregnancy. Measurements of tensile properties of the cervix by conical probes, as used in many earlier studies, probably reflect changes in inner circumference (Harkness, 1964).

Uyldert \& De Vaal (1947) showed that the inner circumference of the cervix still increased during pregnancy in rats whose uterine horns were surgically separated from the cervix, suggesting hormonal control of this change. Oestrogens alone and in combination with progesterone and/or relaxin can increase cervical size and produce small increases in cervical extensibility in non-pregnant and mid-pregnant, ovariectomized rats (Kroc, Steinetz \& Beach, 1959; Cullen \& Harkness, 1960; Zarrow \& Yochim, 1961). Cervical dilatation in the pre-term sheep following fetal dexamethasone infusions was said to be inhibited by progesterone injections (Liggins, 1973) although this has not been supported by more quantitative measurements (Stys, Clewell \& Meschia, 1978).

There is therefore evidence that the ability of the cervix to extend does increase during pregnancy but the hormonal control of this increase is less certain. The objective of the present experiments was to determine the effects of various hormonal manipulations on cervical extensibility in the late pregnant rat. Preliminary results have been published (Hollingsworth \& Isherwood, 1977).

\section{Materials and Methods}

Primiparous Sprague-Dawley rats $(300-450 \mathrm{~g}$ ), of known gestational age (day of finding copulation plug $=$ Day 1$)$, were housed in a daily 13-h light period (07:00-20:00 h). Most of the rat in this colony and photoperiod give birth between 12:00 h on Day 22 and 12:00 h on Day 23. 
After treatment of the rats (see below) they were killed, their cervices removed and cervical wet weight determined. The cervix was defined as the less vascular tissue with parallel lumina between the uterine horns and the vagina (Harkness \& Harkness, 1959; Hollingsworth \& Isherwood, 1978). Weight of total products of conception (fetuses, placentas, amniotic fluid and membranes), and numbers of alive and dead fetuses per litter were routinely determined.

Tensile properties of the isolated cervix were measured by a modification (Hollingsworth \& Isherwood, 1977) of the method of Harkness \& Harkness (1959) and Harkness \& Nightingale (1962). Briefly, the cervix was mounted in a tissue bath containing Krebs-Henseleit (1932) solution at $37^{\circ} \mathrm{C}$. A $60 \mathrm{~g}$ load was applied to a pin placed through one cervical canal while another pin, placed through the other canal, was fixed. This load produced an extension of the cervix. Readings of extension were taken every $\min$ for $5 \mathrm{~min}$ and then every $5 \mathrm{~min}$, generally for $100 \mathrm{~min}$. From these readings cervical inner circumference could be calculated (Harkness \& Harkness, 1959) and a typical result is shown in Text-fig. 1.

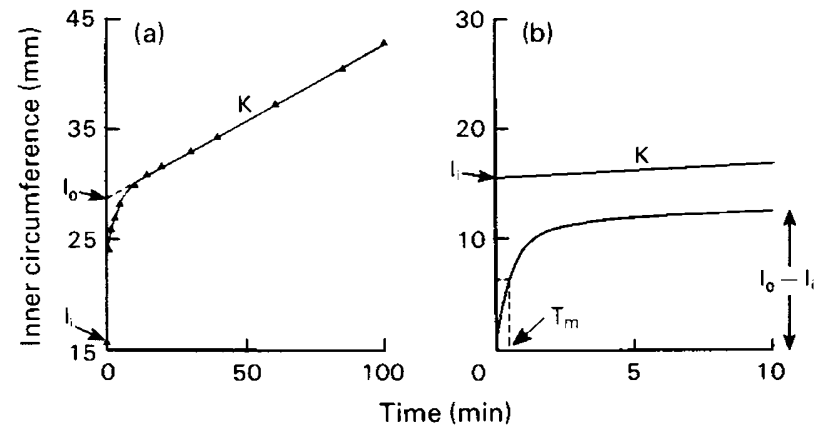

Text-fig. 1. Effect of a 60-g load on the inner circumference of the cervix of a Day-22 pregnant rat; (a) plot of experimental values ( $\mathbf{A}$ ) and calculated line from fit of a hyperbola plus a straight line, and (b) separated into linear and hyperbolic components $l_{i}=$ initial circumference $(\mathrm{mm})$ at 0 min before adding load. $\mathrm{l}_{0}=$ inner circumference $(\mathrm{mm})$ at 0 min obtained by extrapolation of the linear component. $K=$ rate of increase in inner circumference $(\mathrm{mm} / \mathrm{min})$ for the linear component. $T_{m}=$ time to half maximum for hyperbolic component. Cervical extensibility $=10^{3}$ $\mathrm{K} / \mathrm{l}_{0}\left(\mathrm{~min}^{-1}\right)$, which is the fractional increase in circumference per min.

Inner circumference increased linearly with time after an initial curve following application of the load as described by Harkness \& Harkness (1961). The mean circumference of the head of a rat fetus at Day 22 of pregnancy, determined with cotton thread on 84 fetuses, was $43.6 \mathrm{~mm}$. This is approximately the circumference to which the cervical lumina must be stretched at parturition. The use of a NOVA 820 computer (Data General Corporation), a curve-fitting programme (Steven, Podrazký \& Foster, 1978) and data from 10 of our experiments showed that the initial curves were well fitted by a hyperbolic and less well by an exponential component. The curve-fitting programme was given starting values for four parameters, $1_{1}$ (circumference in $\mathrm{mm}$ at zero time before adding load), $\mathrm{l}_{0}$ (inner circumference in $\mathrm{mm}$ at zero time, obtained by extrapolation of the linear component), $\mathrm{K}$ (rate of increase in inner circumference in $\mathrm{mm} / \mathrm{min}$ for the linear component) and $T_{m}$ (time in min to half maximum for the hyperbolic component), which will describe the algebraic sum of a hyperbola plus a straight line. The parameters were independently changed so that both hyperbolic and linear components were fitted simultaneously until the deviations of the computed points from the experimental points reached a minimum. Over $95 \%$ of experiments could be fitted within $1 \mathrm{~mm}$ of the experimental points (Text-fig. 1).

A derived measure of the extensibility of the cervix was used (Harkness \& Harkness, 1961; Harkness \& Nightingale, 1962), namely $10^{3} \mathrm{~K} / 1_{0}$, with units of $\min ^{-1}$, which is the fractional increase in circumference per min, and is independent of between-experiment variations in the size of the inner circumference $\left(\mathrm{l}_{0}\right)$. The measures of the hyperbolic component, $T_{m}$ and $\left(\mathrm{l}_{0}-\right.$ 
$1_{1} / l_{i}$ ), were greater for the cervices of the pregnant rats than for those of the non-pregnant and post-partum rats but were not accurately measured by the current technique. The curve fit was used primarily to obtain a more accurate measurement of extensibility and inner circumference $\left(\mathrm{l}_{0}\right)$.

Oestradiol benzoate (3-benzoyloxyoestra-1,3,5(10)-triene-3,17 $\beta$-diol) and progesterone (pregn-4-ene-3,20-dione) were obtained from Sigma Chemical Co. and injected in arachis oil. Gifts of relaxin, NIH-R-P1 (442 i.u./mg) from NIAMDD, Bethesda, U.S.A., and CMa ${ }^{1}-18$ 28AAE (3000 i.u./mg) from Dr B. G. Steinetz, were injected in saline $(9 \mathrm{~g} \mathrm{NaCl} / 1)$.

Results are presented as means \pm s.e.m. and statistical comparisons were made using the Mann-Whitney U-test (Siegel, 1956).

\section{Results}

Preliminary experiments showed that the mean \pm s.e.m. extensibility $\left(7 \cdot 3 \pm 1 \cdot 3 \mathrm{~min}^{-1}\right)$ and inner circumference $(18.2 \pm 1.0 \mathrm{~mm})$ of cervix of Day-18 pregnant rats after incubation for $2 \mathrm{~h}$ in Krebs-Henseleit solution (1932) were not different from the values of extensibility $(5.8 \pm 0.7$ $\left.\mathrm{min}^{-1}\right)$ and inner circumference $(15.9 \pm 1.1 \mathrm{~mm})$ following $30 \mathrm{~min}$ incubation. All tissues were studied within $2 \mathrm{~h}$ of removal from the rats.

\section{Experiment 1: tensile properties of the cervix during pregnancy}

The cervix of the non-pregnant rat was only slightly extended during 100 min under load but extensibility was increased 8-fold by Day 22 of pregnancy (Table 1). Cervical wet weight and inner circumference increased during pregnancy with a similar time course but proportionately less. By Day 1 post partum extensibility was similar to the non-pregnant value but there was a smaller percentage decrease in wet weight and inner circumference.

Table 1. Properties of the cervix (extensibility $\left(10^{3} \mathrm{~K} / \mathrm{l}_{0}\right)$ and inner circumference $\left.\left(\mathrm{l}_{0}\right)\right)$ and products of conception of the rat during pregnancy and after birth

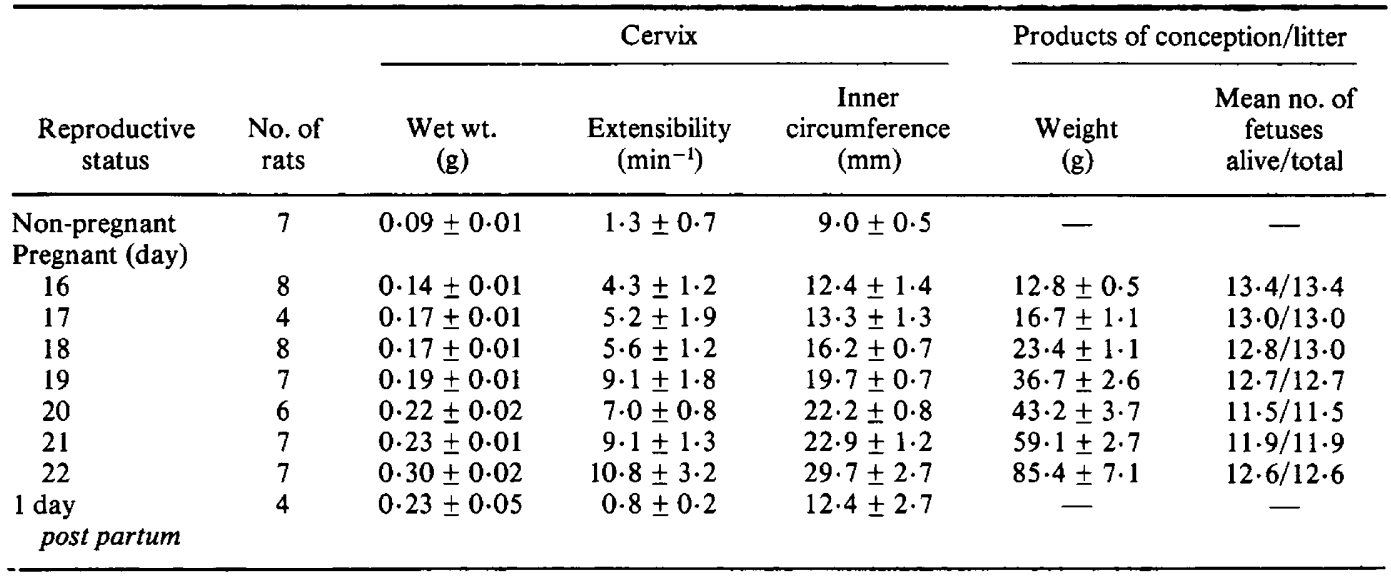

Values are mean \pm 1 s.e.m.

\section{Experiment 2: steroid treatment of intact pregnant rats}

Intact rats at Day 18 of pregnancy were treated s.c. at 09:00 and 16:00 h with 0.5 or $5 \mu \mathrm{g}$ oestradiol benzoate $/ \mathrm{kg}$ or $10 \mathrm{mg}$ progesterone $/ \mathrm{kg}$. The steroids had no effect on cervical extensibility when measured on Day 19 (Table 2). 
Table 2. Effect of oestradiol benzoate or progesterone given twice on Day 18 of pregnancy on the properties of the rat cervix (extensibility $\left(10^{3} \mathrm{~K} / \mathrm{l}_{0}\right)$ and inner circumference $\left(\mathrm{l}_{0}\right)$ ) on Day 19

\begin{tabular}{lcccc}
\hline & & \multicolumn{3}{c}{ Cervix } \\
\cline { 3 - 5 } \multicolumn{1}{c}{ Treatment } & $\begin{array}{c}\text { No. of } \\
\text { rats }\end{array}$ & Wet wt $(\mathrm{g})$ & $\begin{array}{c}\text { Extensibility } \\
\left(\mathrm{min}^{-1}\right)\end{array}$ & $\begin{array}{c}\text { Inner circumference } \\
(\mathrm{mm})\end{array}$ \\
\hline $\begin{array}{l}\text { Control } \\
\text { Oestradiol benzoate }\end{array}$ & 5 & $0.21 \pm 0.03$ & $7.5 \pm 0.7$ & $20.8 \pm 2.5$ \\
$\quad \begin{array}{l}0.5 \mu \mathrm{g} / \mathrm{kg} \\
5.0 \mu \mathrm{g} / \mathrm{kg}\end{array}$ & 8 & $0.19 \pm 0.01$ & & \\
$\begin{array}{l}\text { Progesterone } \\
10.0 \mathrm{mg} / \mathrm{kg}\end{array}$ & 6 & $0.18 \pm 0.01$ & $5.6 \pm 3.3$ & $20.1 \pm 1.3$ \\
\hline
\end{tabular}

Values are mean \pm 1 s.e.m.

\section{Experiment 3: ovariectomy and hormone treatment}

Group 1. Following bilateral ovariectomy of rats on Day 16 of pregnancy most fetuses were alive in rats killed on Day 18 (Group 1a) but many were dead or resorbed in rats killed on Day 20 (Group 1b; Table 3). By Day 20 some fetuses had been expelled while others were lodged at the utero-cervical junction. Cervical wet weight and inner circumference had increased in these rats by Day 20 compared to Day 16 (Table 1) but extensibility had decreased to values seen in non-pregnant rats.

Table 3. Effect of bilateral ovariectomy on Day 16 of pregnancy with and without steroid treatment and relaxin (see text) on the properties of the rat cervix (extensibility $\left(10^{3} \mathrm{~K} / \mathrm{l}_{0}\right)$ and inner circumference $\left(\mathbf{l}_{0}\right)$ ) and products of conception

\begin{tabular}{|c|c|c|c|c|c|c|c|}
\hline \multirow[b]{2}{*}{ Group } & \multirow[b]{2}{*}{$\begin{array}{c}\text { Day } \\
\text { killed }\end{array}$} & \multirow[b]{2}{*}{$\begin{array}{l}\text { No. of } \\
\text { rats }\end{array}$} & \multicolumn{3}{|c|}{ Cervix } & \multicolumn{2}{|c|}{ Products of conception/litter } \\
\hline & & & $\begin{array}{l}\text { Wet wt } \\
\text { (g) }\end{array}$ & $\begin{array}{c}\text { Extensibility } \\
\left(\min ^{-1}\right)\end{array}$ & $\begin{array}{c}\text { Inner } \\
\text { circumference } \\
(\mathrm{mm})\end{array}$ & $\begin{array}{l}\text { Wt } \\
(\mathrm{g})\end{array}$ & $\begin{array}{l}\text { Mean no. of } \\
\text { fetuses } \\
\text { alive/total }\end{array}$ \\
\hline $\begin{array}{l}\text { 1a. Ovariectomy } \\
\text { only }\end{array}$ & 18 & 9 & $0.16 \pm 0.01^{\mathrm{a}}$ & $3.9 \pm 0.8^{\mathrm{a}}$ & $16 \cdot 3 \pm 0 \cdot 8^{a}$ & $24.5 \pm 0.7$ & $12 \cdot 5^{\mathrm{a} / 12 \cdot 8^{\mathrm{a}}}$ \\
\hline $\begin{array}{l}\text { lb. Ovariectomy } \\
\text { only }\end{array}$ & 20 & 7 & $0.28 \pm 0.02^{\mathrm{a}, \mathrm{b}}$ & $1 \cdot 0 \pm 0 \cdot 2^{\mathrm{a}, \mathrm{b}}$ & $29 \cdot 9 \pm 1 \cdot 3^{\mathrm{a}, \mathrm{b}}$ & $21 \cdot 9 \pm 3 \cdot 2^{\mathrm{a}}$ & $3 \cdot 1^{a, b} / 6 \cdot 3^{a, b}$ \\
\hline 2a. Steroids & 19 & 7 & $0.11 \pm 0.01^{\mathrm{c}}$ & $2 \cdot 2 \pm 0 \cdot 3^{\mathrm{c}, \mathrm{f}}$ & $12 \cdot 5 \pm 1 \cdot 3^{\mathrm{c}, \mathrm{d}, \mathrm{e}}$ & $31 \cdot 7 \pm 2 \cdot 0$ & $10 \cdot 9 / 11 \cdot 4$ \\
\hline 2b. Steroids & 20 & 4 & $0.11 \pm 0.01^{\mathrm{b}}$ & $2.8 \pm 0.3^{b}$ & $13.7 \pm 1.7^{\mathrm{b}}$ & $53.8 \pm 1.3^{\mathrm{a}}$ & $13 \cdot 5^{\mathrm{b}} / 13 \cdot 8^{\mathrm{b}}$ \\
\hline $\begin{array}{l}\text { 3. Progesterone } \\
\text { withdrawal }\end{array}$ & 19 & 8 & $0.13 \pm 0.01$ & $2 \cdot 7 \pm 0 \cdot 5$ & $16 \cdot 6 \pm 0 \cdot 7^{c}$ & $40.0 \pm 1.7$ & $14 \cdot 5 / 14 \cdot 5$ \\
\hline $\begin{array}{l}\text { 4. Steroids + } \\
\text { relaxin }\end{array}$ & 19 & 7 & $0.12 \pm 0.00^{d}$ & $3 \cdot 3 \pm 0 \cdot 3^{c, d}$ & $17.9 \pm 1.0^{d}$ & $35 \cdot 1 \pm 1 \cdot 6$ & $12 \cdot 3 / 12 \cdot 4$ \\
\hline $\begin{array}{l}\text { 5. Steroids + } \\
\text { relaxin }\end{array}$ & 19 & 4 & $0.16 \pm 0.01^{\mathrm{c}, \mathrm{d}}$ & $5 \cdot 3 \pm 0 \cdot 8^{d, f}$ & $17.8 \pm 1.6^{\mathrm{e}}$ & $36 \cdot 2 \pm 1 \cdot 8$ & $13 \cdot 0 / 13 \cdot 0$ \\
\hline
\end{tabular}

For details of group treatments see text. Values are mean \pm 1 s.e.m. Values within columns with same superscripts are significantly different $(\mathrm{a}, \mathrm{b}, \mathrm{f} 2 P<0.05 ; \mathrm{c}, \mathrm{d}, \mathrm{e} 2 P<0.01)$.

Group 2. To replace ovarian steroid secretion, other groups of bilaterally ovariectomized rats were injected s.c. with $0.5 \mu$ g oestradiol benzoate $/ \mathrm{kg}$ plus $10 \mathrm{mg}$ progesterone $/ \mathrm{kg}$, once on Day 16 and twice daily on Days 17 and 18 (Group 2a) or Days 17 to 19 (Group 2b), and killed 1 day later (Table 3). This regimen allowed the pregnancies to continue with a normal increase in conceptus weights. However, cervical extensibility had only increased to a small extent, much less than the increase that normally occurs over this period of pregnancy (Table 1).

Group 3. Another group of bilaterally ovariectomized rats were treated s.c. with $0.5 \mu \mathrm{g}$ oestradiol benzoate/ $\mathrm{kg}$ once on Day 16 and twice daily on Days 17 and 18 but $10 \mathrm{mg}$ progesterone $/ \mathrm{kg}$ once on Day 16 and twice on Day 17 only (i.e. progesterone withdrawal). The rats 
were killed on Day 19. In this group inner circumference showed a small but significant increase compared to that in Group 2 a but extensibility had not increased (Table 3).

Groups 4 and 5. In addition to the steroid regimen of Group 2a, animals in Group 4 received s.c. injections of 1000 units relaxin (NIH-R-P1)/kg twice on Day 18 only, while those in Group 5 received $0.5 \mathrm{mg}$ relaxin $\left(\mathrm{CMa}^{1}-18-28 \mathrm{AAE}\right) / \mathrm{kg}$ once on Day 16 and twice on each of Days 17 and 18. In both groups there was increased cervical extensibility on Day 19 and small increases in inner circumference (Table 3 ).

\section{Discussion}

The simple method described in this paper permits measurement of the large increase in extensibility and inner circumference of the rat cervix that occurs during pregnancy, in preparation for the need to dilate at term, and the changes in these produced by hormone manipulation. The increases observed in untreated pregnant rats in the present results confirm the observations of Harkness \& Nightingale (1962) and Rundgren (1974).

The cervix of the late pregnant rat contains smooth muscle which is capable of responding to prostaglandins, oxytocin and neurotransmitters, but on Day 22 maximal responses of spirally cut cervical strips were small relative to those of the uterine horn (Hollingsworth \& Isherwood, 1978, 1979), perhaps due to the lower proportion of smooth muscle in the cervix (Harkness \& Harkness, 1959). It is therefore reasonable to account for changes in the extensibility of the cervix mainly in terms of changes in the connective tissue.

There is only limited information on the possible hormonal control of the increase in cervical extensibility during late pregnancy in the rat (see 'Introduction'). The present results and those of others (Csapo \& Wiest, 1969; Catalá \& Deis, 1973; Buckle \& Nathanielsz, 1975) show that parturition after ovariectomy in late pregnancy in the rat is protracted, fetal and neonatal deaths occur and often fetuses are lodged in a cervical canal. This could be due to a lack of an ovarian hormone to provide the terminal increase in cervical extensibility. Sufficient cervical dilatation could still occur to allow fetal expulsion as fetal head circumference would be less than at term and the stresses of the fetal head would appear to be exerted for a longer period of time. Uterine motility, as measured by intrauterine balloons in conscious rats, was considerably greater in ovariectomized than control pregnant animals (M. Hollingsworth \& C. N. M. Isherwood, unpublished).

The ovarian hormone producing increased cervical extensibility could be an oestrogen. Oestrogens increased cervical weight and inner circumference in the non-pregnant rat but produced only small increases in cervical extensibility (Kroc et al., 1959; Cullen \& Harkness, 1960; Zarrow \& Yochim, 1961). The changes in the cervix described by Kroc et al. (1959) and Zarrow \& Yochim (1961) are probably mainly reflections of increased tissue mass rather than greater extensibility. Oestradiol administered in large doses to women at term produced some cervical softening as judged clinically (Pinto, Fisch, Schwarcz \& Montiori, 1964; Gordon \& Calder, 1977). In the present work, oestradiol benzoate and progesterone had no effect on cervical extensibility when given to intact rats but the combination of progesterone and oestradiol benzoate produced a small increase when given to ovariectomized rats. The dosages of progesterone and oestradiol benzoate used are similar to those which will, respectively, return plasma progesterone concentrations to normal values following ovariectomy (Csapo \& Wiest, 1969) and produce normal delivery following ovariectomy near term (Catalá \& Deis, 1973). Also, the increases in extensibility during pregnancy described here and by Harkness \& Nightingale (1962) and Rundgren (1974) precede the rise in plasma oestradiol concentrations near term (Shaikh, 1971).

Progesterone is able to increase slightly cervical weight and inner circumference above that of oestrogen-treated rats but does not increase extensibility (Kroc et al., 1959; Cullen \& 
Harkness, 1960; Zarrow \& Yochim, 1961). As peripheral plasma concentrations of progesterone decline in the late pregnant rat from about Day 17 or 18 (Csapo \& Wiest, 1969; Buckle \& Nathanielsz, 1975) increased cervical extensibility could be a direct consequence of progesterone withdrawal. However, cervical extensibility decreases following ovariectomy when plasma progesterone concentrations will have fallen (Csapo \& Wiest, 1969) and extensibility could not be significantly increased with the progesterone-withdrawal treatment used in the present study. Fitzpatrick (1977a, b) has suggested that increased cervical softening can only be produced in sheep with dexamethasone or prostaglandin F-2a or in the goat with cloprostenol when there are low progesterone concentrations or a low progesterone/oestrogen ratio. Progesterone may have an inhibitory action on the cervix, preventing other hormones from increasing cervical extensibility. Other methods of producing progesterone withdrawal are necessary to test this further.

Another hormone synthesized and stored in rat ovaries is relaxin (Anderson \& Long, 1978). Serum relaxin concentrations in pregnant rats, as measured by radioimmunoassay, reach a peak about Day 15 and then slowly decline (O'Byrne \& Steinetz, 1976). This peak precedes the rise in cervical extensibility in rats and there is some correspondence between serum relaxin concentrations and increased cervical size in the pregnant hamster (O’Bryne, Sawyer, Butler \& Steinetz, 1976). Ovariectomy would remove the source of relaxin in the rat and this could explain the minimal increase in cervical extensibility in the ovariectomized, steroid-treated group. Treatment with relaxin increased cervical extensibility and further experiments are necessary, using different doses and schedules of relaxin, to determine whether extensibilities equivalent to those seen at term could be produced in ovariectomized, steroid-treated rats.

This work was supported by a grant from the Lalor Foundation. We thank Miss D. Longman for technical assistance, the staff of the mechanical workshop, Medical School, Manchester University, for the apparatus to measure cervical extensibility, and NIAMDD, Bethesda, U.S.A., and Dr B. G. Steinetz for supplies of relaxin.

\section{References}

Anderson, M.L. \& Long, J.A. (1978) Localization of relaxin in the pregnant rat. Bioassay of tissue extracts and cell fractionation studies. Biol. Reprod. 18, 110 117.

Buckle, J.W. \& Nathanielsz, P.W. (1975) A comparison of the characteristics of parturition induced by prostaglandin $F-2 \alpha$, infused intra-aortically, with those following ovariectomy in the rat. J. Endocr. 64, $257-266$.

Catalá, D. \& Deis, R.P. (1973) Effect of oestrogen upon parturition, maternal behaviour and lactation in ovariectomized pregnant rats. J. Endocr. 56, 219 225.

Csapo, A.I. \& Wiest, W.G. (1969) An examination of the quantitative relationship between progesterone and the maintenance of pregnancy. Endocrinology 85, 735-746.

Cullen, B.M. \& Harkness, R.D. (1960) The effect of hormones on the physical properties and collagen content of the rat's uterine cervix. J. Physiol., Lond. 152, 419-436.

Fitzpatrick, R.J. (1977a) Dilatation of the uterine cervix. In The Fetus and Birth (Ciba Fndn Symp. No. 47), pp. 31-39. Eds. J. Knight \& M. O'Connor. Elsevier, Amsterdam.
Fitzpatrick, R.J. (1977b) Changes in cervical function at parturition. Annls Rech. vét. 8, 438-449.

Gordon, A.J. \& Calder, A.A. (1977) Oestradiol applied locally to ripen the unfavourable cervix. Lancet ii, 1319-1321.

Harkness, M.L.R \& Harkness, R.D. (1959) Changes in the physical properties of the uterine cervix of the rat during pregnancy. J. Physiol., Lond. 148, 524-547.

Harkness, M.L.R. \& Harkness, R.D. (1961) The mechanical properties of the uterine cervix of the rat during involution after parturition. J. Physiol., Lond. 156, $112-120$.

Harkness, R.D. (1964) The physiology of the connective tissues of the reproductive tract. Int. Rev. Connect. Tissue Res. 2, 155-211.

Harkness, R.D. \& Nightingale, M.A. (1962) The extensibility of the cervix uteri of the rat at different times of pregnancy. J. Physiol., Lond. 160, 214-220.

Hollingsworth, M. \& Isherwood, C.N.M. (1977) Changes in the extensibility of the cervix of the rat in late pregnancy produced by prostaglandin $F_{20}$ ovariectomy and steroid replacement. Br. J. Pharmac. 61, 501-502P.

Hollingsworth, M. \& Isherwood, C.N.M. (1978) Mechanical responses of the isolated cervix and uterine 
horn of pregnant rats near term to drugs. $B r . J$. Pharmac. 63, 513-518.

Hollingsworth, M. \& Isherwood, C.N.M. (1979) Mechanical responses of the isolated cervix of the day 22 pregnant rat to field stimulation. Experientia 35, $72-73$.

Krebs, H.A. \& Henseleit, K. (1932) Untersuchungen uber die hanstoffbildung im tierkörper. HoppeSeyler's Z. Physiol. Chem. 210, 33-66.

Kroc, R.L., Steinetz, B.G. \& Beach, V.I. (1959) The effects of progestagens and relaxin in pregnant and non-pregnant laboratory rodents. Ann. N.Y. Acad. Sci. 75, 942-980.

Liggins, G.C. (1973) Hormonal interactions in the mechanism of parturition. Mem. Soc. Endocr. 20 , 119-139.

O'Byrne, E.M. \& Steinetz, B.G. (1976) Radioimmunoassay (RIA) of relaxin in sera of various species using an antiserum to porcine relaxin. Proc. Soc. exp. Biol. Med. 152, 272-276.

O'Byrne, E.M., Sawyer, W.K., Butler, M.C. \& Steinetz, B.G. (1976) Serum immunoreactive relaxin and softening of the uterine cervix in pregnant hamsters. Endocrinology 99, 1333-1335.

Pinto, R.M., Fisch, L., Schwarcz, R. \& Montiori, E. (1964) Action of estradiol $17 \beta$ upon uterine contrac- tility and the milk-ejecting effect in the pregnant woman. Am. J. Obstet. Gynec. 90, 99-107.

Rundgren, A. (1974) Physical properties of connective tissue as influenced by single and repeated pregnancies in the rat. Acta. physiol. scand., Suppl. 417.

Shaikh, A.A. (1971) Estrone and estradiol levels in the ovarian venous blood from rats during the estrous cycle and pregnancy. Biol. Reprod. 5, 297-307.

Siegel, S. (1956) Nonparametric Statistics for the Behavioural Sciences. McGraw Hill, New York.

Steven, F.S., Podrazký, V. \& Foster, R.W. (1978) Incremental analysis. The application to quantitation of both enzyme activity and inhibitory activity in complex subcellular fractions. Analyt. Biochem. 90, 183-191.

Stys, S.J., Clewell, W.H. \& Meschia, G. (1978) Changes in cervical compliance at parturition independent of uterine activity. Am.J. Obstet. Gynec. 130, 414-418.

Uyldert, I.E. \& De Vaal, O.M. (1947) Relaxation of the rat's uterine ostium during pregnancy. Acta brev. neerl. Physiol. 15, 49-53.

Zarrow, M.X. \& Yochim, J. (1961) Dilation of the uterine cervix of the rat and accompanying changes during the estrous cycle, pregnancy and following treatment with estradiol, progesterone and relaxin. Endocrinology 69, 292-304.

Received 30 August 1978 